\title{
THE CONSUMER'S STAKE IN THE FINANCE COMPANY CODE CONTROVERSY
}

\author{
David F. Cavers*
}

A consideration of instalment selling problems as they affect the ultimate consumer cannot disregard the rôle played by the finance company. But for the development of the finance company, instalment credit could never have expanded to its present tremendous proportions, Certainly this is true with respect to the merchandizing of automobiles, and the automobile has long held a place of preëminence among commodities sold on instalment credit. ${ }^{1}$

The finance company does not lend directly to the purchasers of goods the sale of which it finances, but in discounting the notes given by such purchasers to the retail dealer, the finance company is in a position to determine at least the minimum credit terms which time purchasers must meet. Since, as will be seen, the financing of instalment sales is a highly competitive business, it becomes important to examine the practices of that business to ascertain their influence upon the cost to the consumer of instalment credit financed through these agencies.

This inquiry into competitive practices in the sales finance business is facilitated by the effort on the part of the "finance company industry" to regulate those practices by the adoption of a Code of Fair Competition under the National Industrial Recovery Act. These efforts, which led to the submission of a code in September, 1933, on which a public hearing was held the following month, were not successful, nor have they as yet been successful, in bringing about the adoption of any code by

- B.S. in Econ., 1923, University of Pennsylvania; LL.B., 1926, Harvard. Member of New York Bar. Professor of Law, Duke University. Editor, Law and Contemporary Problems. Contributor to legal periodicals.

${ }^{2}$ Milan V. Ayres, Analyst of the National Association of Finance Companies, estimated the volume of instalment credit lent in 1925 at $\$ 4,066,000,000$. Of this amount, nearly $\$ 2,300,000,000$ represented automobile financing. See Clark, Financing the Consumer (1930) I7. Professor Seligman's study of the extent of instalment credit for the same year brings the average amount of instalment credit about 20 per cent lower, but the predominating position of the automobile remains unchallenged. I SElroman, ECONOMICS OF INSTALMENT CREDIT (1927) II7-119. Of an estimated instalment sales volume in 1931 of $\$ 1,355,000,000$ for new automobiles, refrigerators, radios, furniture, sewing machines, vacuum cleaners, and oil burners, automobiles comprised over 50 per cent, $\$ 697,500,000$. The Anticipated Dollar (Jan. 1933) 7 Fortune 68, 69. Moreover, the proportion of instalment sales handled through finance companics is especially high in the case of automobiles. 62.5 per cent of the new automobiles sold in r931 were purchased on instalment credit. Ibid.

"It may seem anomalous to apply the term "industry" to a business of this character, but, under the nomenclature of the NRA codes, all businesses became "trades" or "industries." The term "finance company industry" was used in the code proposed for sales finance companics. 
this industry. The discussions which centered about proposals for a code have, however, rendered available a considerable body of information concerning competitive practices within the industry, upon which this study is based.

Before undertaking a discussion of these practices, it is first essential to examine the composition of the industry itself, an inquiry which will throw light on the difficulties encountered in formulating a code acceptable both to a numerical majority of its constituent organizations and to a majority in terms of the volume of business done. ${ }^{3}$

\section{The Organization of the Industry}

The financing business as comprehended by the code proposed for the finance company industry does not extend to the making of direct loans on chattel security but is limited to the purchase of receivables (contracts, notes, drafts, title retention instruments, etc.) held by dealers in commodities sold on credit. However, some companies engaging in sales financing also engage in the making of direct loans. The business does embrace the financing of commodities sold by wholesalers as well as by retailers, but the problems relating to this branch of the business are without the scope of this paper. ${ }^{4}$

Although to an increasing extent finance companies participate in the financing of other commodities than automobiles, the automobile business furnishes, it has been estimated, a total of 90 per cent ${ }^{5}$ of the total volume of receivables financed. The bulk of this business is concentrated today in the hands of three companies, General Motors Acceptance Corporation (G. M. A. C.), Commercial Investment Trust, Inc. (C. I. T.), ${ }^{B}$ and Commercial Credit Company (C. C. C.). The first of these is a subsidiary of General Motors Corporation; the other two have affliations with a number of automobile manufacturers ${ }^{7}$ including General Motors' principal competitors, the Commercial Investment Trust, through its subsidiary, the Universal Credit Company, with Ford, and the Commercial Credit Company with Chrysler. These companies are known to the trade as the "Big Three," a term which I shall employ for convenience in reference. In 1933, the capital and surplus of the Big Three totalled $\$ 179,500,000$, about 63 per cent of the total capital and surplus of $\$ 266,700,000$ of all units of the industry reporting their net worth to Dun and Bradstreet, Inc. ${ }^{8}$

"The NIRA requires that groups proposing codes be "truly representative" of their respective industries. NIRA, Tit. I, $\$ 3$ (a) 49 STAT. 196 (1933), I5 U. S. C. A. (Supp. 1934) \$703 (a). In the interpretation of this provision by the NRA, it has been the general-but not the universal-practice to require that both the criteria indicated in the text above be met.

tThe textile factoring business was expressly excluded from the submitted Finance Company Industry Code.

${ }^{6}$ See Statement of Robert P. Babcock representing the Code Committee, Hearing on a Code of Fair Competition for the Finance Company Industry, NRA, Oct. $26,1933,39$. (The record of the hearing on this code will be cited hereinafter as "Hearing.") This estimate excludes the factoring business.

- This company has acquired the Universal Credit Company which has affiliations with Ford.

"The precise character of the contractual relations constituting these "affiliations" is not known. It is believed that the manufacturer undertakes to recommend the affiliated finance company to his dealers and their customers.

${ }^{8}$ See Exhibit $\mathrm{H}$ filed by the Code Committee at the code hearing. Apparently all but a small portion of the industry in terms of net worth is included in this figure. 
The total volume of business of the Big Three has been estimated at 75 per cent ${ }^{\circ}$ of the entire volume of business handled by the industry.

The remainder of the business is in the hands of a large number of companies, estimated in October, 1933 , to total 785 , of which 212 did not operate in the automobile finance business. ${ }^{10}$ The companies include two (termed "semi-nationals") which operate over a considerable territory, but most of them operate either locally or over a relatively restricted regional area. They do not have affliations with automobile manufacturers. These companies 'will be referred to herein as "the independents." (It should be remarked at this juncture that the Big Three do not finance all the sales of the automobiles manufactured by the companies with which they are affiliated.)

\section{Operating Methods in the Industry}

Not only is there a marked difference in size and scale of operations between the Big Three and the independents but there is a significant difference in their operating procedure. A finance company enters the retail sale transaction through the sale and indorsement to it by the dealer of the car purchaser's note for the unpaid balance and financing charges on the purchased car. As the business originally developed this indorsement was with recourse, i.e., it subjected the dealer to liability on the note in the event of default by the maker-purchaser. About r 920 some finance companies began to operate a non-recourse plan: $i . e$., the purchaser's note would be indorsed by the dealer to the finance company without recourse, thereby freeing the dealer from all liability on the contract. The dealer was paid the cash price at the time of sale, the difference between the cash price and the time price being absorbed by the finance company. Since the recourse of the finance company in such a transaction was against the purchaser only, the importance to the finance company of scrutinizing each transaction to determine the credit risk involved was materially enhanced. The burden of collection and of realization on the security in case of default was also assumed by the finance company. The non-recourse plan consequently offered a very real attraction to the dealer in relieving him of these responsibilities; it also imposed duties on the finance companies employing it which could best be discharged by companies which operated locally and were enabled thereby to keep close watch over the purchasers whose notes they held. ${ }^{11}$

The additional services rendered by the non-recourse companies led at first to the imposition of higher rates to the dealers on paper discounted on this plan. But as the non-recourse business became more firmly established, the demand for cars being high and repossession losses low, competitive conditions began to bring rates to the dealer between companies operating on that plan and those operating on a recourse basic closer together. In the meantime however, a significant development was

'Statement of Harry B. Dyer, Central Acceptance Corp., Cincinnati, Ohio, Hearing, I65.

${ }^{10}$ See Exhibit H, supra note 8.

"For a discussion of the two plans, see I Seligman, op. cit. supre note $x, 75-81$. 
taking place in the practice of companies which had heretofore operated on the recourse plan. The repurchase plan was introduced.

Under this plan the dealer does not undertake unlimited liability on the paper indorsed by him but does obligate himself to repurchase cars repossessed by the finance company on default by the purchasers. The repurchase price is fixed at the unpaid balance due on the purchaser's note, and may include expenses incurred by the finance company in repossessing the car. The dealer is not obligated to the finance company in the event of the loss or destruction of the car. ${ }^{12}$ Other immunities were granted him as repurchase experience became wider and finance companies could act as self-insurers against certain of the risks.

The repurchase plan was accompanied by an arrangement known as the dealer reserve, ${ }^{13}$ for the protection of the dealer against losses incurred by him in the resale of the repossessed car. A certain percentage of the amount of each receivable discounted was set aside by the finance company as a reserve to the account of the dealer. In the event of a repossession loss, his reserve was available to absorb it, so that the dealer was liable to make further payment to the finance company only to the extent that repossession losses exceeded the amount of accumulated reserves to his credit. When reserves exceeded a percentage fixed with reference to the total receivables outstanding against the dealer, the excess was paid to him by the finance company to offset any losses which he might incur. For the efficient dealer whose repossession losses were few, the reserve might thus afford a source of additional income.

The repurchase agreement coupled with the dealer reserve was, needless to say, a powerful competitive weapon in the hands of the Big Three. ${ }^{14}$ It enabled them to maintain uniform their rate structure with respect to the financing charges paid by automobile purchasers and at the same time permitted them to meet the competition of the non-recourse companies in the localities where these were strongest by restricting the risk which the dealer had formerly assumed under the recourse agreement and by providing for compensation against losses. In addition, the accumulation of

${ }^{12}$ See Statement of Harry Weiss, National Bond and Investment Co., Hearing, at II4, quoting from "a bulletin issued by the largest repurchase automobile finance company, in July, 1933." According to this bulletin the dealer is relieved from liability:

1. For damages which are the direct result of a collision, provided the repossession took place because of such collision.

2. In casc of conversion of an automobile.

3. In case of confiscation of an automobile by federal or state authorities.

4. If a "repossessed car is not returned to the dealer before the account is 90 days delinquent."

Mr. Weiss asserted that "the dealer protective agreement has been broadened far beyond its meaning in that these larger repurchase finance companies reimburse the dealers for damages to repossessed cars not caused by collision, but instead, extraordinary wear and tear and other causes." Id. at II5.

${ }^{23}$ The dealer reserve device may be, and apparently is, employed by finance companies operative on 2 recourse basis but not employing repurchase agreements.

1t It should be observed that these plans are not employed exclusively by the Big Three, nor do they use them in all their transactions. Some independents conduct a recourse business with or without the repurchase plan. Still more handle both recourse and non-recourse transactions. Non-recourse business is, however, characteristic of the great majority of the independents. 
funds to the dealer's account in the hands of the finance company tended very naturally to the maintenance of relations between him and the company. ${ }^{15}$

Many of the non-recourse companies responded to the pressure of this competition, not by the reduction of rates to the purchaser, but by the payment of bonuses to dealers financing through them. This practice was not nation-wide. It was most general in the Middle West. ${ }^{16}$

As operated by most companies, apparently the amount of the reserve credited to the dealer under the repurchase plan and the amount of the bonus paid under the non-recourse plan was not fixed but varied from dealer to dealer, depending chiefly on competitive conditions. ${ }^{17}$ As competition grew more acute with the onset of the depression, these practices extended until they threatened in some localities to undermine the stability of the sales finance business. Moreover, especially in the Middle West, dealers, who themselves were hard-pressed by lowered commissions on a lowered sales volume and by the necessity of granting increasingly large trade-in allowances, began to take advantage of the situation created by competition among the finance companies for their business. ${ }^{18}$ Not content with the reserve or bonus offered them by the finance companies, some dealers began the practice of "loading" the finance charge with an extra charge, apparently calculated with reference only to what the traffic would bear. This sum, the "pack," merged in the finance charge and invisible to the car purchaser, was collected by the finance company as part of the contract, but the dealer retained it immediately as a part of his payment for the paper by the finance company.

\section{Proposals for Code Regulation of the Reserve, Bonus, and "Pack".}

The situation created by these practices was thoroughly unsatisfactory to the vast majority of finance companies. No doubt it would have been still more so to the consumers who footed the bill, but they were innocent of any knowledge of the tribute levied on them. ${ }^{19}$ The companies, however, faced the problem which faces every business in which business-buying becomes a competitive practice: no single company dared abandon the practice without the assurance that its competitors would reform also; and until June, I933, there was no apparent way of assuring simultaneous reformation. The enactment of NIRA seemed to offer an outlet from the impasse. The National Association of Finance Companies (N.A.F.C.), ${ }^{10^{4}}$ with

\footnotetext{
${ }^{25}$ In the event that the dealer severs his relation with the finance company, apparently the practice is to withhold these reserves until the outstanding receivables have been retired:"

${ }^{16}$ It has been said not to exist in New England. Statement of D. W. Hinckley, Ass'n of New England Finance Companies, Hearing, 63.

17 "Deputy Whiteside: Do these rates vary up and down according to business conditions by a single company or are they fairly fixed? Mr. Babcock: They vary in accordance with competition, I believe, rather than in accordance with economic conditions." Hearing, 36.

18 "Today the first question any dealer asks when you solicit business is 'How much rebate do I get?" !' Statement of D. B. Cassatt, Interstate Finance Corp., Dubuque, lowa, Hearing, 127.

${ }^{10}$ Some complaints do reach the Better Business Bureaus. See Statement of Harry Van Horn, President, Nat. Ass'n of Better Bureaus, Hearing, 73 ef seq.

${ }^{204}$ This organization is now entitled the National Association of Sales Finance Companies.
} 
a membership of 201 companies, including the Big Three, representing a very substantial proportion of the automobile financing business of the nation, undertook the preparation of a code containing provisions designed to curb business-buying through excessive reserves, bonuses, and "packs."

The code which was finally formulated and submitted to the NRA represented, it was said, ${ }^{20}$ a "compromise" between those employing the dealer reserve and those operating on the non-recourse plan. Paragraph (2) of Section 5 of Article VI ("Fair Trade Practices") prohibited the inclusion in any receivable arising from an automobile retail sale "of any amount for financing in excess of the amount deducted and/or retained for financing by" the finance company, and also prohibited the repayment "to the dealer or to any other party in any manner or form" of any part of the amount so "deducted and/or retained." $U_{p}$ to that point this provision would have eliminated dealer reserve, bonus, and "pack," but the concluding words "except as hereinafter provided in this section" paved the way for the preservation of the dealer reserve in the succeeding paragraphs which are set forth in full below:

"In transactions between the dealer and the [finance] company wherein the dealer assumes a definite and actual contractual liability (in the event of repossession of the motor vehicle from the sale or lease of which the receivable arose) by reason of repurchase agreement, or endorsement, or assignment and guaranty to the company in connection with the sale and assignment of such receivable to the company, involving the dealer's liability for loss and expense on the repossession, repurchase, and resale of such repossessed motor vehicle, repossession loss reserves may be credited by the company to the account of the dealer:

"(a) Such reserves shall be limited as follows: On new passenger car receivables, one and one half per cent $(\mathrm{r} 1 / 2 \%)$ of the amount of the receivable; on used passenger car receivables, three per cent $(3 \%)$ of the amount of the receivable with a minimum of $\$ x 0.00$ and a maximum of $\$ 25.00$ on such used passenger car receivable; ${ }^{21}$ and on each light delivery truck receivable, either new or used, an additional $\$ 5.00$ may be credited.

"(b) Such reserves shall be accumulated without interest allowance to the credit of each dealer's account with the company up to a minimum of three per cent of such dealer's outstanding retail receivables, and shall so subsequently be maintained, any excess, as and when it may develop, to be paid to the dealer in the discretion of the company.

"(c) In all events repossession losses and expenses incident thereto of parent

${ }^{20}$ Statement of Robert P. Babcock, supra note 5, at 34 .

${ }^{2}$ Author's note: In a substantial number of cases, the inclusion of these minima will result, of course, in a reserve much higher than the percentage indicated. The average amount of used car receivables reported to the Bureau of the Census for the year 1932 was $\$ 241$. The \$10 minimum represents slightly over 4 per cent on the average receivable. On cheap used cars it might equal ro per cent or more. However, the proponents of the code state that the loss ratio on used car repossessions equals two and one half times that on new cars, Statement of Robert P. Babcock, supra note 5, at 44, whereas the percentage reserve for used cars is only twice that for new. 
and/or affiliated and/or subsidiary companies shall be charged to the aforementioned repossession loss reserves before payment of such reserves to the dealer.

"(d) The Code Authority ... shall at the request of any three companies inquire into the adequacy or inadequacy of such reserves in the locality affected and shall make such adjustments as may be necessary subject to the approval of the Administrator."

The proposed code containing the foregoing provisions was presented to a convention of the N.A.F.C. on September 23, 1933. It was carried by a vote of 82 to 22.22 But soon after its adoption, the minority members girded their loins for battle. A regional association; the Mid-West Finance Conference, was promptly organized to voice the views of the dissenting groups. In the two weeks prior to the public hearing on the proposed code, the Conference mustered 357 objecting companies, including 38 companies which had attended the convention and either voted in favor of the code or abstained from voting. The volume of business handled by the 357 dissenting companies was estimated at "approximately $\$ 350,000,000$."23 Accordingly, the stage was set for a major battle when the code hearing convened in Washington on October 26, 1933.

The principal targets of attack were the provisions preserving the dealer reserve while abolishing the bonus paid under the non-recourse plan. The proponents of the code argued that the maximum rates in the code for dealer reserves were "substantially lower than the reserves [then] existing on recourse receivables" and that therefore those non-recourse companies which were already competing against higher dealer reserves without paying bonuses could continue to operate successfully under the lower code reserves. ${ }^{24}$ The proponents pointed to the provision permitting sectional adjustments by the Code Authority, varying code rates, as affording a means of eliminating local inequalities. ${ }^{25}$ They declared their adherence "to the principle that there is no justification for a bonus on receivables purchased without recourse and therefore without contractual liability, and that any provision for such a bonus would tend to unnecessarily increase the cost to the consumer."26 In statements in behalf of the code from companies operating in the South ${ }^{27}$ and on the Pacific Coast, ${ }^{28}$ it was suggested that a 2 and 4 per cent reserve rate was needed; New England companies on the other hand regarded the $I \frac{1}{2}$ and 3 per cent reserve as too high for that region. ${ }^{29}$ All these groups looked, however, to the Code Authority to

\footnotetext{
${ }^{23}$ Statement of Robert P. Babcock, supra note 5, at 8. Owen L. Coon, representing the Mid-West Finance Conference, states the vote as having been 79 for, 25 against. Hearing, 82 .

${ }^{23}$ The organization of the Mid-West Conference is described in the statement of Owen L. Coon, supra note 22, at 79-9r. This conference developed into the American Finance Conference, a national organization operating independently of the N. A. F. C.

${ }^{24}$ Statement of Robert P. Babcock, supra note 5 , at 44

${ }^{25} \mathrm{Id}$. at 45.

${ }^{27}$ Statement of W. D. Troyer, General Finance Co. of Louisiana, Inc., Hearing, 59.

23 Ibid.

${ }^{20}$ Statement of D. W. Hinckley, supra note 16 , at 63 .
} 
rectify the situation by sectional adjustments if experience indicated such adjustment to be necessary.

The burden of the argument on behalf of the objecting companies ${ }^{30}$ was that dealer reserves were unnecessary, ${ }^{31}$ that the reserves established in the proposed code were higher than the losses which the dealers would actually realize, that consequently the reserves in fact constituted a concealed rebate, and that the non-recourse companies, prohibited by the code from paying bonuses, would be at the mercy of their competitors which employed dealer reserves or would themselves be forced to operate under the repurchase plan. They asserted that sectional adjustments could be brought about too slowly to enable them to retain their dealer customers, and they questioned whether the provisions for sectional adjustments which were subject to the veto power of the Big Three ${ }^{32}$ offered satisfactory prospects that such changes could be achieved.

Some of the speakers for objecting non-recourse companies conceded that they paid bonuses to dealers but insisted that they did so unwillingly. The reserve and bonus alike were repeatedly denounced as "commercial bribery," and solicitude was frequently voiced for the purchasing public. ${ }^{33}$ Running throughout the statements of opposition speakers was a thread of hostility of "little business" toward "big business." The code, it was asserted, would "tend to promote a monopoly and discriminate against small enterprises." 34 It was urged that, if the dealer reserve were eliminated, then the recourse companies "could offer cheaper rates, and cheaper rates mean easier sales for the dealer. He could advertise those cheaper rates and sell more automobiles . . . and set up his own reserve, if he wants to, and derive much higher profit by increasing volume of business." 35 The preponderant minority view seemed in favor of the outright abolition of both reserve and bonus, but, under questioning by Deputy Administrator Whiteside who presided, one speaker conceded

${ }^{30}$ The objections to the code raised by the dissenting companies were reiterated so frequently in the course of the hearing that citations to individual statements do not seem useful. Criticism of the dealer reserve provisions extends from page $\times 12$ through page 180 of the record of the hearing and crops out oceasionally in the discussion of other points.

${ }^{31}$ It was pointed out that the dealer reserve is not employed in the financing of instalment sales of other commodities.

whe Code Authority was to include ten members from the industry and one or more non-voting members appointed by the Administrator. Rules for their selection guaranteed a representation of three to the Big Three companies. Submitted Code for the Finance Company Industry, Art. VII, \$x. (Hereinafter cited as the "Submitted Code.") Acts of the Code Authority required the concurrence of threefourths of the members eligible to vote. Id. $\$ 9$.

"This attitude was also expressed by proponents of the code. Sec, e.g., Statement of Robert P. Babcock, supre note 5, at 29. Neither side carried this attitude to the extreme of devoting any consideration to the problem of statement of finance charges which was raised only in the proposals made by the representative of the Consumers' Advisory Board, Miss Constance Kent. The Board's proposals are set forth in Foster and Foster, Rate Aspects of Instalment Legislation, supra, at p. 193. For Miss Kent's statement, see Hearings, 97-99.

"Statement of Harry B. Dyer, supra note 9, at 165.

${ }^{25}$ Statement of Samuel Schleimer, Gotham Credit Corporation, Hearing, 168. He pointed out that his company operated in a used car field which was not invaded by the recourse companies, but insisted that if the independents were driven from the new car field they would be thrown into the used car business "and we will all be scrambling for the bones." Id. at 169 . 
that the basis of his objection was that the reserve percentage set was too high, not the existence of the reserve. ${ }^{36}$

The position of the proponents of the code in answer to the arguments of the dissenters is difficult to determine from an examination of the record of the hearings since no opportunity for rebuttal was afforded. ${ }^{37}$ Incidentally, no representative of the Big Three spoke at the hearings. Some clue to the proponents' position may be derived from the charge circulated by the N. A. F. C. that "The objections to the code have been confined to those who prefer to continue to pay bonuses to dealers selling their paper on a without recourse basis." ${ }^{38}$ This charge was repeatedly denied by representatives of the dissenting companies.

Deputy Administrator Whiteside who presided and who professed to be "totally ignorant of this business"39 directed most of his inquiries to the questions of whether the dealer reserve subserved a useful function and of whether the gravamen of the dissent lay in the existence of the reserve or in the figure set in the code for it. ${ }^{40}$

Although other points of difference arose which will be discussed subsequently in this paper, the reserve and bonus problem seems to have been the rock on which this effort to establish a code split. Attempts by the NRA to bring the parties together in the months that followed were unsuccessful. In January, I934, a code was proposed,which included a provision designed to eliminate the "pack" but was silent as to reserve and bonus. ${ }^{41}$ Although both groups were agreed on the desirability of abolishing the "pack," they were not ready to leave the problem of reserve and bonus undetermined. In May, 1934, the NRA submitted a proposed code to the industry which would have eliminated both bonus and reserve. ${ }^{42}$ Needless to

\footnotetext{
${ }^{26}$ Statement of Paul Jones, President Mid-West Finance Conference, Hearing, 207. Mr. Jones is now president of the successor organization, the American Finance Conference, which is opposed to all reserves, regardless of the percentage.

st The procedure of code hearings precluded argument in rebuttal. Moreover, speakers were forbidden to controvert specifically statements made by prior speakers. See Hearing, 80 .

${ }^{28}$ Quoted in Statement of Owen I. Coon, supra note 22, at 90.

Hearing, 156. He is, however, an experienced credit man, having been President of Dun \& Bradstreet, Inc.

${ }^{10} \mathrm{Sec}$, passim, Hearing, 150-161, 176-180. The explanation which is generally advanced in justification of the assumption by the finance companies of the burden which had formerly rested on the dealer, i.e., the establishment of a reserve against losses, is that the dealer, selling an article at a price publicly advertised by the manufacturer on credit terms established by the finance company, is not in a position to increase either the price or the finance charge to take care of risks of loss incidental to reselling. The reserve is asserted to be substantially similar to, although perhaps smaller than, that which a non-recourse company would have to set up for its own protection.

\$1 The provision reads as follows: "Art. VII. Fair Trade Practices-Automobile Financing. Section 3. Misrepresentation. No company shall purchase or otherwise acquire any receivable.... (b) wherein the dealer has added to the selling price to the customer in constructing the time price any amount in excess of the differential fixed by the company in its chart in the hands of the dealer; provided that this subsection (b) shall not apply to bulk purchases of reccivables which the dealer has carried in his own portfolio for a longer period than ninety (90) days, if not so carried in contemplation of avoiding the spirit and interest of this section or to receivables or trucks selling for more than \$1500."

${ }^{13}$ Section 5 (a) of the article dealing with Fair Trade Practices contains a general prohibition against the giving of bonuses or other gratuities to dealers by finance companies. Paragraph (b), directed to the reserve, provides as follows: "No company shall in connection with the purchase of a receivable, set up any reserve for the purpose of creating a credit for a dealer. Any money held on the effective date of
} 
say, this proposal did not prove acceptable to the Big Three. More surprising, however, it was not endorsed by the dissenting independents who were not satisfied by the composition of the Code Authority or the "factory coercion" clause which will be discussed in a succeeding section.

Again, in July, I934, the NRA returned to its January proposal designed to eliminate the "pack" but to leave the dealer reserve and bonus subject to future regulation. ${ }^{43}$ The Code Authority was authorized, upon concurrence of threequarters of the companies "both numerically and by volume of business," to recommend "further fair trade practice provisions" to the Administrator for inclusion in the code. ${ }^{44}$ Possibly the existence of this power or the statutory power of the President to modify his approval of the code ${ }^{45}$ rendered the antagonists reluctant to come under a code while the principal point of difference between them remained unsettled. Moreover, by this time, other provisions in the code had assumed a greater importance, as will be seen below, and the problem of effecting a satisfactory compromise had grown more formidable.

Not long after there emanated from the American (née Mid-West) Finance Conference a proposed code, dubbed by its sponsors the "Workable Code." The "Workable Code" included a provision for the elimination of the "pack" similar to that contained in the Administration's proposal, ${ }^{46}$ and then met the problem of the reserve and bonus by a provision authorizing both, but setting a maximum limit of 2 per cent of the unpaid balance in the case of new car paper and 4 per cent in the case of used car paper. ${ }^{47}$ This solution seems to have been unacceptable to the Big Three and also to the Administration which was reluctant to sanction the payment of any bonus for which no service was rendered.48 The "Workable Code," however, was approved by 25 companies. ${ }^{40}$

To an observer who is enrolled in neither camp, one fact seems evident, namely, the lack of facts, facts sufficiently comprehensive and sufficiently authoritative to serve as the basis of judgment. A number of representatives of the dissenting companies

this code by a company on behalf of a dealer arising from the purchase of a receivable shall be returned to such dealer within ninety ( 90$)$ days of the effective date of this code."

$\checkmark$ For the relevant provision, see note $4 \mathrm{I}$, supra.

"Code proposed by NRA, July, r934, Art. VI, \$6 (b).

${ }^{4}$ NIRA, Tit. I, S10 b, 48 STAT. 200 (1933), I5 U. S. C. A. (Supp. 1934) \$710 (b).

"A "Workable Code," Art. VII, $\$ 3$ (b). This provision follows in substance the language of paragraph (b) in the Administration code, supra note $4 \mathrm{I}$, up to the proviso.

" "Workable Code," Art. VII, \$3 (c). "Section 3. Misrepresentation. No company shall purchase or otherwise acquire any receivable $\ldots$ (c) wherein the dealer and/or anyone connected therewith shall participate in the finance charge in any transaction directly or indirectly in an amount in excess of $2 \%$ of the unpaid balance (cash delivery price less down payment) on new car paper and in excess of $4 \%$ of the unpaid balance (cash delivery price less down payment) on used car paper."

${ }^{20}$ Dealers operating under a non-recourse plan often do render some services to the finance company both in the collection of accounts and in the disposal of repossessed cars. They are not under obligation to perform these services, however, nor is the amount of the bonus measured with reference to their extent.

¿ 19 companies dissented. 204 companies did not indicate their position. Am. Finance Conference, The Business of Automobile Financing (1934) 15. 
offered evidence to show that, operating under the non-recourse plan where their liability was not limited as is the dealer's who operates under a repurchase agreement, their losses ran substantially below the reserves against dealer's limited losses. ${ }^{50}$ But how representative the losses sustained by those companies are of the experience of dealers generally is difficult to tell. They may represent the effect of greater care in the selection of credit risks than finance companies operating with manufacturer affiliations are in a position to make. They may reflect a selection of dealers whose operating experience is better than average. Again, since most of the loss ratios offered were based on periods of time extending back to the New Era of blessed memory, they may not be representative of credit experience under the depression and the New Deal. Before a definitive appraisal could be made of the submitted code's dealer reserve provisions on the score of their fairness as between the competing branches of the industry, it would seem essential that an extensive survey of loss ratios be undertaken by an impartial agency, preferably the Research and Planning Board of NRA.

It must be conceded, however, that the problem is one which accuracy in factfinding alone cannot solve. It is certain that any such survey would reveal significant variations in loss ratios from region to region throughout the nation and from dealer to dealer within each region. Even if regional reserve rates were established, the efficient dealer whose losses ran below the regional average would find in the reserve a source of profit. If reserves were abolished but finance companies undertook to reimburse dealers for their actual losses, the inefficient or careless dealer, whose business today non-recourse companies properly refuse to carry, would in effect receive a subsidy which would have to be reflected in the finance charges of companies operating nationally. A possible escape from this dilemma might be for such companies to reimburse actual dealer losses but not in excess of the regional average loss ratio. ${ }^{50 *}$

\section{The Consumer's Interest in the Reserve-Bonus Issue}

But the consumer is a party in interest to this controversy, as both sides have freely admitted. What is his stake in the controversy? Certainly it is apparent that the existing situation operates to his disadvantage. ${ }^{51}$ In some instances where com-

${ }^{60}$ One loss ratio ran as low as .32 per cent on a ten year average. Statement of D. B. Cassatt, supra note 18 , at 133 . One statement based on an analysis of 150 companies prepared for the N. A. F. C. indicated a loss ratio of .86 per cent. Statement of Harry Weiss, supra note 12, at 120. Mr. Weiss quoted from a bulletin issued by one of the Big Three to dealers in which the dealer reserve feature of this company's plan was stated to have been a source of profit to dealers prior to 1930. The reserve percentages were the same as those in the submitted code.

son A set-up of this sort. would seem permissible under a code forbidding both dealer reserves and bonuses since the suggested reimbursement of dealer losses amounts to in substance to the adoption of the non-recourse plan of operation, adapted to the needs of finance companies which must serve varying types of dealers.

ox "The importance of the elimination of this evil can be understood when we are advised that the amount that was taxed the purchasers of automobiles during the year I933 was between $\$ 40,000,000.00$ and $\$ 60,000,000.00$." AM. Finance Conference, op. cit. supra note 49 , at 20 . It is not entirely clear whether this estimate is confined to dealer reserves or includes bonuses and "packs." 
petition was acute, the field of competition seems to have been removed from that of service to the purchaser to that of compensation to the dealer. It was asserted in the course of the hearing that with the introduction of the dealer reserve and the retaliatory bonus, the trend toward lower finance charges which had been in process theretofore came to an end and that thereafter economies in financing operations were reflected, not in lower finance charges to the car purchaser, but in larger payments by the finance companies to the dealer. ${ }^{52}$ More recently, the tendency has been to lower the charge to the purchaser.

However, before it is assumed that these practices, including even the notorious "pack," represented entirely an unjust exaction from the consumer, another question must be answered: did the increase in the dealer's compensation through repayments out of finance charges represent more than a fair offset to the reduction in the dealer's compensation as seller of the car? The dealer is entitled to a fair return for the services he performs. In the depression period, when car prices and volume of sales were falling, the dealer's profit on sales fell with them. Moreover, since a buyer's market prevailed, he was obliged to make trade-in allowances which cut into this narrowed profit-margin. Loss ratios were higher. Beset by these difficulties, it seems likely that many dealers would have gone to the wall if they had not derived an additional income from dealer reserves, bonuses; and "packs." Yet while the effect of these practices may have been to assure to the dealer no more than a fair reward for his services, they operated to distribute the burden of contributing to his income unfairly as between his cash and credit customers. The latter in effect subsidized the former.

Whatever the force of this argument may have been before the adoption of the Code for the Motor Vehicle Retailing Trade, the effect of the operation of that code in tending to stabilize trade-in allowances ${ }^{53}$ has been to weaken it appreciably. The dealer today, with better assurance of a fair profit on his sale transaction, has less claim to an added increment through the financing charge. ${ }^{54}$ This relationship of dealer compensation to the problem of finance company practices points, moreover, to a basic difficulty inherent in seeking the solution to that problem through the code of a single industry. In addition to the consumer, there are three parties in

5 Statement of Milton Epstein, Wisconsin Ass'n of Finance Companies, Hearing, 143. Mr. Epstein was speaking on the basis of his own company's experience. Information as to the cost of instalment financing to the consumer is difficult to obtain. See Froman, The Cost of Installment Buying (I933) II HARV. Bus. REv. 227.

s See Code for the Motor Vehicle Retailing Trade, Art. IV, A. The only provision in that code rélating to finance charges is the following: "Charges for financing retail conditional sales shall be upon an equitable basis to consumer and dealer. No dealer in financing conditional retail sales shall charge a lower rate than the lowest or a higher rate than the highest rate charged by regularly established finance companies operating in the same district as the dealer," Id., Art. IV, B (3). It would seem that this provision operates only where the dealer himself finances retail sales and that therefore it would not prevent the "pack" since the "pack" is merged in the finance charge.

st It is asserted, however, that gains under the code have been largely offset by reductions in the profitmargin on new car sales allowed by manufacturers to dealers. See Am. Finance Conf. News, Feb. 19, 1935. 
interest to the retail sale ${ }^{55}$ of an automobile, the dealer, the finance company, and the manufacturer. A Code of Fair Competition for any one of these industries, drafted as it must be by the members of that industry and imposing its sanctions upon them only, must perforce deal with the problem in piece-meal fashion. And when all three industries have thus made their individual contributions to the problem, it is not to be wondered at if they do not dovetail perfectly.

Moreover, even if there were not this piece-meal treatment of a problem affecting an integrated economic process, one might still question whether any code structure, in the formulation of which the consumer's interests were relegated to secondary position, could be expected to function satisfactorily. The abuses of the reserve, bonus, and "pack" were made possible only because of the utter want of intelligent consumer interest in financing charges. The automobile purchaser responds promptly to variations in the f.o.b. price of competing makes of cars; he approximates the horse-trader in the matter of trade-in allowances; but he has been as gullible as a child when confronted by a finance charge. Perhaps there is still some psychological impediment to self-assertion on the part of one who must ask for credit, routinized as that transaction has become. But however that may be, it is evident that an aggressive campaign on the part of finance companies stressing lower credit costs would have overcome any such inhibition. The failure on the part of the industry to adopt this tactic has all but nullified the effectiveness which the consumer might have had as an ally in the enforcement of code provisions designed to overcome those abuses which victimize the purchasing public as well as disrupt the industry. One may doubt, indeed, whether, if the proposed code had been adopted, it would have proved enforceable unless, either through additional code requirements or through a change in competitive policies, the companies had aroused the car purchaser's interest in financing costs and thereby enlisted his aid in stamping out over-charging.

\section{Proposals for Code Regulation of Credit Terms}

The other code provisions about which debate centered had little bearing on the consumer's relation to this problem. The submitted code contained no specific provisions governing either the method of stating or the amount of the credit charge, allowance for prepayments, or the exercise of the finance company's legal remedies. One provision ${ }^{56}$ was directed at dealer misrepresentation, prohibiting the purchase of "any receivable arising from a retail sale or lease of any passenger automobile or light delivery truck wherein, to the knowledge of the company, the terms and conditions of the transaction have been misrepresented." (Heavy duty trucks are seldom financed under the ordinary plans; hence, apparently, their exception.) Two grants

\footnotetext{
${ }^{8}$ The problem of financing wholesale transactions has not been considered in this paper. It is evident, however, from the inclusion in the submitted code (Art. VI, \$2) of a prohibition against wholesale financing below cost, that the dealer has occupied a favored position in this respect. Unduly low wholesale rates must be reflected in higher retail rates.

${ }^{56}$ Submitted Code, Art. VI, $\$ 5$ ( $\mathrm{r}$ ).
} 
of power were accorded the Code Authority to deal with other abuses. Section I of Article VI ("Fair Trade Practices") provided as follows:

"Retail.Credit Terms. Retail credit terms involved in receivables acquired by companies shall be subject to regulation by the Code Authority ... with respect to any problems, sectional or otherwise, which exist or may arise from time to time."

Section 6 of the same article was even more general. It read:

"Other Business Practices. Various practices which are not herein specifically defined and the practices herein referred to, to the extent that problems with respect thereto may arise which are peculiar to certain sections or circumstances, shall be referred to the Code Authority ... whose duty it shall be to regulate them in a manner equitable to all concerned, subject to approval by the Administrator."

Except for a protest against Section I filed by the National Retail Dry Goods Association, ${ }^{57}$ these sections and the problems blanketed by them escaped discussion. Despite their sweeping terms, their potentialities were straitly limited by the requirement of a three-fourths vote as a prerequisite to Code Authority action. ${ }^{58}$

The codes proposed by the NRA went somewhat farther in this direction, except that their fair trade practice provisions were limited to automobile financing. The provision against misrepresentation, substantially the same as that quoted above, did not exclude any type of car. ${ }^{59}$ A provision in the code proposed in July, x934, struck at the use by dealers of more than one rate chart for each make of car. ${ }^{30}$ These codes required receivables purchased by finance companies to carry on their face or on an accompanying memorandum the following information "set out in the manner and form indicated below":

"(a) Cash delivery price including extra equipment.............

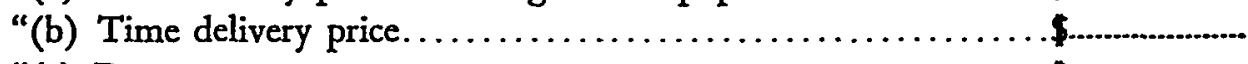

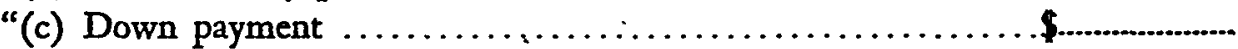

"(d) Balance due $\ldots \ldots \ldots \ldots \ldots \ldots \ldots \ldots \ldots \ldots \ldots \ldots \ldots$

"(e) Number of instalments, amount of each and due date thereof. .\$

“(f) Nature of insurance coverage, if any...................

"A true and correct copy of the data as given above has been given to the purchaser or lessee in the transaction above referred to.

"Signed.............................................."

These codes also dealt with the matter of pre-payments, providing for an allowance, on bona fide offers to pay the unpaid balance, of "not less than six per cent

or This Association objected to this regulation of retail credit terms as potentially impairing the competitive position of retail dry goods merchants resorting to finance companies as against those who did their own financing. It also broadly attacked this section as an unjustifiable limitation on individual initiztive and vewed with alarm the perils to "the consuming public" arising from such control. Statement of Irving C. Fox, Nat. Retail Dry Goods Ass'n, Hearing, ro7-rog.

- Submitted Code, Art. VIII, 59.

- Code proposed by NRA, July, I934, Art. VII, \$3 (a). Earlier proposals contained a similar provision.

${ }^{\infty}$ Id. 53 (c). IId. 95. 
per annum on the total amount to be paid on each individual payment, computed for the number of days by which such payment is prepaid."62

The "Workable Code" contained provisions substantially similar to those appearing in the Administration codes on these points. ${ }^{.3}$

\section{Proposals for Code Regulatton of "Factory Coercton" and "Sudsidies"}

The questions other than the dealer reserve and bonus problems which did excite controversy, at the hearing and thereafter, related chiefly to the composition of the Code Authority, "factory coercion," and "factory subsidies." A consideration of the first of these questions is without the scope of this paper; as one might surmise, it reflected the divergence in interests between the Big Three and the independents. The other questions must be dealt with briefly.

"Factory coercion" is the exercise of coercive pressure by a manufacturer upon a dealer to dispose of his receivables to a finance company owned by or affiliated with the manufacturer. Although denying that such coercion existed, ${ }^{04}$ the Big Three who alone might be its beneficiaries acquiesced in the insertion of the following provision in the submitted code:

"Factory Coercion. No company shall permit or sanction any solicitation of business whereby the dealer is required under threat, direct or indirect, to dispose of his receivables to such company." ${ }^{85}$

Representatives of dissenting companies insisted that coercion did exist in the industry and made plain their belief that the code provision was toothless. ${ }^{.0}$ In proposing alternative provisions, however, some difficulty was encountered in the fact that coercion relates to dealer-manufacturer relationships whereas the code could extend its sanctions only to finance companies. ${ }^{\text {ot }}$ Deputy Whiteside, moreover, pointed to the difficulty of controlling a practice so "intangible" in character ${ }^{88}$ and termed "very good" the provision in the submitted code. "You will find," he added, "if "if you ask attorneys about it, that it is quite difficult to make one any stiffer, because we tried to do it."

Two of the Administration's codes repeated the original provision; the May, 1934, proposal added a reinforcing clause. ${ }^{20}$ However, the "Workable Code" drafted by

๘Id. \$6.

a "Workable Code," Art. VI, \$3 (2) (misrepresentation), \$5 (credit terms), \$6 (pre-payment allowance). No restriction to the use of one rate chart was included.

G Statement of Robert P. Babcock, supra note 5, at 31 .

${ }^{\infty}$ Submitted Code, Art. VI, $\$ 3$.

${ }^{\circ}$ The statements of G. A. Pivirotto, Automobile Finance Co., Pittsburgh, Pa., Lew Fleming of the Associates Investment Co., South Bend, Ind, and Abraham Cooper, Union Investment Co., Detroit, Mich., were addressed to the question of coercion. See Hearing, r 80-rgr.

${ }^{6}$ See Hearing, 185 .

Id. at I86.

$\infty$ Id. at 187 .

T0 The new clause which was added to the coercion provision set forth in the text, supra, read as follows: "nor shall any company accept or acquire any receivables where the dealer, to the knowledge of the company, has been required, under threat or force, direct or indirect, on the part of any automobile manufacturer to dispose of such receivables to such company." 
the independents emerged with a much more elaborate and formidable interdiction. Its rigorous tenor can be indicated by the last two of the five sentences comprising it.

"Coercion.... No finance company shall purchase any receivables from any dealer where any coercion or demand, either direct or indirect, has been made in its behalf, with the knowledge of the finance company, compelling or requiring or inducing the automobile dealer to transact his business with or dispose of his receivables to such finance company. Any factory owned or factory affliated company shall be presumed to have knowledge of any and all acts of its affiliate or of the company by which it is owned." 71

The Big Three, needless to say, did not find this provision "workable." Although they denied the existence of coercion, they pointed to the risk of harassing complaints by the independents which their very numbers and the indefinable character of coercive action would make probable. In an effort to meet this objection which had also been raised with respect to the NRA's own provision, the NRA had undertaken the preparation of a provision contemplating the imposition of a penalty for the bringing of complaints without probable cause when further code negotiations were suspended in the fall of 1934 .

From the standpoint of the consumer, the harmfulness of coercion, if it exists, would lie in the fact that it constitutes a competitive practice bringing no direct benefit to him and thereby depriving him of the fruits of normal competition. But, as has been seen, these fruits have not thus far been abundant. Moreover, so long as competition between manufacturers persists, it is not clear that a monopolization of the financing business by their affiliates would necessarily be detrimental to automobile purchasers. The problem of factory coercion does not, therefore, seem to be of primary importance from the consumer standpoint, however significant it may be to the dealer and independent finance company.

"Factory subsidies" are payments made by a manufacturer to finance companies to enable them to reduce charges for financing the former's products. Apparently such subsidies were at one time paid by automobile manufacturers, but it was generally agreed at the code hearing that the practice had been discontinued. ${ }^{72}$ No prohibition of such subsidies was contained in the submitted code, and Deputy Administrator Whiteside took the position that its inclusion was undesirable so long as the practice was not subsisting. He suggested that if the practice were to recommence, the Code Authority could make "ample provision for that." ${ }^{1722}$ This did not serve to quiet the demand for the interdiction of the subsidy, however, and the

72 "Workable Code," Art. VII, \$4.

${ }^{72}$ See Statements of John E. Davis, National Guaranty Finance Co., Hearing, 195, Lew Fleming, id. at 197. The speaker dissented from this view. Statemeno of Harry B. Dyer, supra note 9, at I98. A provision prohibiting subsidies was successfully opposed by a representative of one of the Big Three companies when it was proposed for inclusion in the submitted code. He expressed fear that some manufacturer would bring out a "low rate finance plan" to meet which it would be necessary for his company to receive a subsidy. See Am. Frnance Conference, op. cit. supra note 49 , at 31 .

T2 Hearing, 196. 
"Workable Code" included a provision ${ }^{73}$ prohibiting subsidies unless recorded with the Administrator and available to all finance companies.

The time purchaser, of course, benefits directly from the subsidy. Whether this benefit is at the expense of the cash purchaser depends on whether it enables a manufacturer to expand his market sufficiently to permit a reduction in, or at least to maintain, the cash price. Except where the subsidy is employed to induce the financing of a new product which finance companies are otherwise unwilling to handle, it gives the recipient a great competitive advantage. Its indirect consequences to the consumer depend, accordingly, upon the importance of maintaining the independent finance companies as a competitive factor in the industry.

The prevailing uncertainty as to the future of the NRA renders difficult prediction as to the future of efforts to regulate competitive practices in the finance company industry by a code of fair competition. Certainly the obstacles encountered in the formulation of a code for this industry at a time when the Blue Eagle flew high in the land renders the prognosis extremely unfavorable. But the effort to subject finance company practices to code regulation has served to bring the issues dividing the industry into the open. As a consequence, the abuses thus disclosed are less likely to persist. What the reforming forces will be is matter for conjecture, but it seems not improbable that they will include the following: (r) Voluntary efforts on the part of the industry to curtail rebating to dealers. ${ }^{74}$ (2) A growing interest on the part of automobile purchasers in the cost of financing. (3) Competition among finance companies in the offering of lower financing charges to the public. ${ }^{75}$ (4) Regulatory state legislation of instalment sale credit terms and competitive practices. ${ }^{76}$ An early application of the first three forces might render the last superfluous.

"Workable Code," Art. VII, \$7.

7 A measure which should operate to diminish the dealer's opportunity to add a "pack" to the finance charge is illustrated in a bulletin issued by the Chrysler Corporation to all De Soto dealers: "The new Dealer franchise for $\mathbf{2} 935$ will carry a proviso that Chrysler Motors products sold to the public on a time payment plan basis shall not carry a larger financing charge than the charge set forth in the official Chrysler Motors Commercial Credit Company's plan for the territory and that time buyers be furnished the insurance cover provided by said plan." Quoted in AM. Finance Conference, op. cit. supra note 49 , at 29 , which sets forth the bulletin as evidencing factory coercion. It is believed that other manufacturers affiliated with the Big Three have adopted similar franchise conditions.

${ }^{70}$ That greater efforts to arouse consumer interest in finance charges may be anticipated in the future is suggested by a national newspaper advertising campaign undertaken this winter by G. M. A. C. in which the public was urged to employ a chart provided in the advertising to check "costs and other differences in time payment plans." "If there is a difference, you should know it."

${ }^{76}$ Since the completion of this article, I have received a copy of the Indiana Retail Installment Sales Act, Ind. Acts r935, H. B. 377, which establishes a licensing system for sales finance companies doing business in that state, to be administered by the Department of Financial Institutions. The Act, which constitutes the first far-reaching attempt to regulate this business, is too long for complete summarization in this paper. Its principal provisions with respect to rates are set forth in Foster and Foster, Rate Aspects of Instalment Legislation, supra, at p. I94. Especially revelant to the issues on which the code controversy focussed arc the sections summarized below: Section 9. No dealer may assign any retail contract to any person other than a licensee. Section ro. No part of the finance charge may be repaid by the finance company to the dealer in excess of an amount to be fixed by the Department and this maximum is to be fixed "without regard to any differentiation as to whether" the contract is assigned on the recourse, non- 
rccourse, or repurchase plan. Section 21 . Conditions in sales by a manufacturer to a dealer that the dealer shall assign his retail contracts only to designated licensees are declared unlawful when their effect "may be to lessen or eliminate competition." Section 22. "Any threat, express or implied, made directly or indirectly" by a manufacturer to a dealer to discontinue sales to the latter unless he assigns his retail contracts to a designated licensec shall be "prima facie evidence" of a condition prohibited by Section 21 . Section 23. Any similar threat by a licensee affliated with a manufacturer shall be presumed to be at the direction of the latter and shall be prima facie evidence of an illegal condition. Section 24 . Subsidies by manufacturers to licensees are prohibited if their effect "may be to lessen or eliminate competition."

The resemblance between these provisions and those of the "Workable Code" is marked, and the Act obviously represents a legislative victory for the independents. The Act burgeons with constitutional problems, and it seems safe to predict that it will not long go untested. 